Brown University has received a grant of $\$ 118,431$ from the U.S. Department of Education's Title II-C Program for cataloging of poetry broadsides-published between 1682 and the present-in the John Hay Library. The grant will fund a retrospective conversion of 16,500 titles in order to give online access to this material.

\section{The Council on Library}

Resources has received a $\$ 350,000$ grant from the Andrew W. Mellon Foundation of New York toward support of general operating expenses over an 18-month period.

The National Endowment for the Humanities has awarded grants totalling $\$ 282,423$ to four university libraries to provide conservation training for library staff members. The University of California, Berkeley; Emory University; the University of Utah; and the University of Washington will train 43 staff members in 42 different libraries in their regions as part of a national plan to improve training in library collections' conservation and preservation.

\section{Rutgers University's Alexander Library}

has been awarded a \$500,000 matching grant from the National Endowment for the Humanities to help create a high-technology scholarly communications center. The new facility will include an information laboratory with $25 \mathrm{com}$ puter workstations, a 100-seat video communications hall capable of satellite transmission and video conferencing, and a humanities and social sciences data center.

\section{The University of California, Berkeley,} has received a four-year, $\$ 4$ million federal grant

Ed. note: Entries in this column are taken from library newsletters, press releases, and other sources. To ensure that your news is considered for publication, write to: Grants \& Acquisitions, C\&RL News, 50 E. Huron St., Cbicago, IL 60611-2795. Photos related to your neus will be considered for publication. to develop and test new technologies to put digital libraries on the information highway. The grant is funded through a joint initiative of the National Science Foundation, the Department of Defense Advanced Research Projects Agency, and the National Aeronautics and Space Administration. The project's focus is to find better ways to collect, store, and organize information in digital forms, and to make it available for searching, retrieval, and processing via communication networks.

\section{The University of California, Los Ange-}

les, Library has been awarded an HEA II-C grant of $\$ 143,500$ by the Department of Education to complete the recataloging and retrospective conversion of 11,200 rare titles in its Children's Book Collection. When complete, the project will result in the addition of over 4,500 new bibliographic records to the OCLC database.

\section{Wright State University Libraries, Ohio,} along with public television station WGBH Boston has been awarded a grant of $\$ 17,500$ and matching funds of up to $\$ 5,000$ from the Ohio Humanities Council to create an original documentary film about the life and times of Wilbur and Orville Wright for The American Experience. The film, which will rely heavily upon original photographs and other source material housed at the Wright State University Libraries, will premiere at the university.

\section{Acquisitions}

\section{The Graham Greene Library and Ar-}

chive, the largest official archive of the late British author in existence, has been acquired by Boston College's John J. Burns Library of Rare Books and Special Collections. The collection consists of 3,000 volumes, many of them annotated, and 60,000 individual documents. Included are letters from Charlie Chaplin, Rich- 


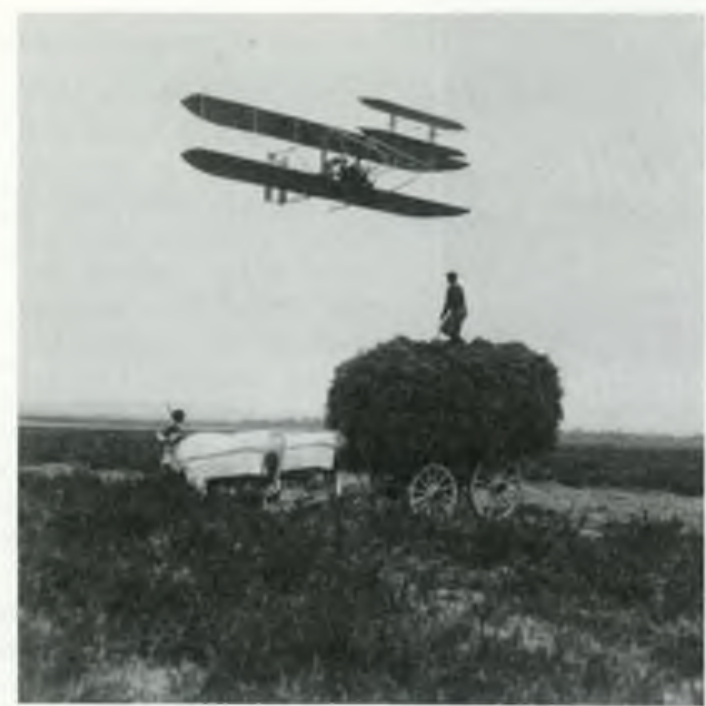

Wilbur Wright demonstrates an early model engine-powered airplane over a farmer's field in Pau, France, in 1909. From the collections at Wright State University.

ard Attenborough, Alec Guinness, and Margaret Thatcher as well as several thousand carbon copies of Greene's own letters, providing both sides of all personal and professional correspondence. These letters were kept meticulously by Greene's sister Elizabeth, who acted as his secretary for 25 years. The library also contains Greene's own works as well as 500 presentation copies from many well-known authors.

\section{The Henry David Thoreau Collection,}

assembled over a 30-year period by Cleveland industrialist Samuel Thomas Wellman II, has been acquired by the Ward M. Canaday Center at the University of Toledo. The collection is a virtually complete assembly of Thoreau's writing and publications, including four first editions, the Blake editions of Thoreau's seasonal writings taken from his journals, the Riverside edition of Thoreau's works (10 volumes), and the Walden edition of Writings (20 volumes, 1906). Also included are many secondary sources that examine the writer's life, his works, and his times.

\section{A donation of 25,000 science fiction,}

adventure, and pulp fiction books and magazines has been acquired by the University of Buffalo's Lockwood Library. Included in the collection, donated by alumnus George Kelley, are nearly 10,000 mystery novels; a variety of sci-fi story anthology magazines, many dating back to the 1950s; a complete set of Galaxy Magazine, issues of Locus and many other "fanzines"; and an original copy of Junkie by William Burroughs.

\section{A portrait of George Gershwin by}

the Mexican muralist David Alfaro Siqueiros, which was originally bequeathed to the University of Texas at Austin over 30 years ago, will arrive at its final destination next year. The painting, which depicts Gershwin seated at a grand piano with various family members and friends in the front rows, was completed in 1936 and is considered significant in that its composition anticipates some of the principles which Siqueiros used in his future murals. The painting had been on long-term loan to the Metropolitan Museum of Art, which had been unaware of the bequest by Ira Gershwin and his wife, Lenore. The museum recently uncovered the bequest and has made arrangements to transfer it to the Ransom Center in late 1996.

\section{A gift of more than $\mathbf{7 0 0}$ volumes on} military history from the personal collection of Jack Fowler of Topeka, Kansas, has been received by Washburn University's Mabee Library. The volumes cover most historical periods with a special emphasis on the U.S. from the Civil War through the Vietnam Conflict. A retired infantry colonel, Fowler is a research attorney for a Kansas Supreme Court justice. He formerly taught at the U.S. Army Command and General Staff College at Fort Leavenworth, Kansas.

\section{The files of Moody Church of Chicago} are now available to researchers at the Archives of the Billy Graham Center at Wheaton College. The files contain correspondence, reports, photos, and other records about American home and foreign missions, the development of Sunday schools, and documents by or about many leaders of American fundamentalism and Evangelicalism. A large part of the collection consists of the correspondence of $\mathrm{H}$. A. Ironside, sometimes call the "bishop of Fundamentalism." The records, which were given to the Archives in 1986 , roughly cover 1915 to 1950 , with the earliest dating from 1872 and the most recent from the 1980 s. 